\title{
The Use of Metadiscourse Markers in Malaysian Undergraduate Persuasive Essay Corpus at Universiti Malaysia Kelantan
}

\author{
Amaal Fadhlini Mohamed ${ }^{1}$, Radzuwan Ab Rashid ${ }^{2}$, Nor Hazwani Munirah Lateh ${ }^{1}$, Yohan \\ Kurniawan $^{1}$ \\ \{fadhlini@umk.edu.my ${ }^{1}$,radzuwanrashid@unisza.edu.my², hazwani.1@umk.edu.my ${ }^{1}$ \}
}

Center for Language Studies and Generic Development, Universiti Malaysia Kelantan, Bachok, 16300, Kelantan, Malaysia ${ }^{1}$, Faculty of Languages and Communication, Universiti Sultan Zainal Abidin, Gong Badak, 21300, Kuala Nerus, Terengganu, Malaysia²

\begin{abstract}
Metadiscourse in undergraduate essay writing is the linguistic expressions used by student writers to organise written texts while interacting with their imaginary readers. This paper presents a preliminary study to discover and present the use of metadiscourse markers in persuasive essays written by a group of undergraduate students from a chosen public university in Malaysia, Universiti Malaysia Kelantan. For the purpose of this study, a simplified metadiscourse framework for ESL lay writers proposed by Tan et al. (2012) is used. The metadiscourse markers in a corpus of undergraduate persuasive essays were explored with the assistance of a concordance software, WordSmith Tools. The findings reveal the frequency of the metadiscourse markers in the corpus and how they are commonly utilised in sentences. This study is expected to pave the way for more studies related to metadiscourse in undergraduate essays from other universities across this country.
\end{abstract}

Keywords: Metadiscourse, organisational discourse markers, Interpersonal Discourse Markers undergraduate essays, persuasive essays.

\section{Introduction}

Persuasive writing is commonly introduced to undergraduate students in many universities or private colleges in Malaysia. They learn this type of essay writing in their English language courses during early semesters. The goal of a persuasive essay is mainly to get readers to agree with an opinion about a topic. The writers use general facts based on his knowledge and include emotions in writing to convince the readers to get on his side. They imaginatively know who their possible readers are and will write to persuade the readers to agree with his opinions. Therefore, persuasive essays are more personal and emotional in nature. They eventually use many ways to interact with the readers especially by using metadiscourse.

Studies show that metadiscourse contributes to effective writing as the ideas become more organised, clear and understandable [4], [3], [1]. Metadiscourse is defined as a way of communications between writers to readers, speakers to listeners or writers to themselves which is not a part of content or idea mentioned, to deliver and organise messages effectively [3], [2], [1], [5]. Each metadiscourse marker has possibly multiple functions according to the context of the sentence. Therefore, many definitions of metadiscourse have explained various roles and functions of metadiscourse in undergraduate writing for further investigation.

For the purpose of this study, a simplified metadiscourse framework for ESL lay writers' introduced by Tan et al.'s [6] was used to search for metadiscourse in MUPE corpus. It is a new version of metadiscourse taxanomy which is designed for lay leaners of especially L2 undergraduates as shown in Table 1. 


\section{Kresna Social Science and Humanities Research}

Proceedings of the International Conference On Ummah:

Digital Innovation, Humanities And Economy (ICU: DIHEc) 2020

https://doi.10.30874/ksshr.38

Table 1: Tan's simplified metadiscourse framework for ESL lay writers (2012)

\begin{tabular}{|c|c|c|}
\hline Category & Function & Example \\
\hline Organizational & \multicolumn{2}{|l|}{ Help writer to manage the flow of ideas } \\
\hline \multicolumn{3}{|l|}{ Connectives: } \\
\hline i) Inter-sentential linkers & $\begin{array}{l}\text { Expressions that link one idea to } \\
\text { the next (between two sentences) }\end{array}$ & $\begin{array}{l}\text { Thus } \\
\text { In addition }\end{array}$ \\
\hline $\begin{array}{l}\text { ii) Intra-sentential } \\
\text { linkers }\end{array}$ & $\begin{array}{l}\text { Expressions that link one idea to } \\
\text { the next (within a sentence) }\end{array}$ & $\begin{array}{l}\text { Thus, } \\
\text {....and..... } \\
\text {...but..... } \\
\text {.....yet..... }\end{array}$ \\
\hline Sequencers & Contribute to the staging ideas & Finally/to conclude/next \\
\hline Topicalizers & $\begin{array}{l}\text { Stating the purpose or intention of } \\
\text { the writer }\end{array}$ & $\begin{array}{l}\text { My purpose here is to....., in the } \\
\text { essay, I am going to....., }\end{array}$ \\
\hline Pointers & $\begin{array}{l}\text { linking current information with } \\
\text { preceding or forthcoming } \\
\text { information }\end{array}$ & $\begin{array}{l}\text { Noted above/ see Fig/in section } 2 \text {, } \\
\ldots . \\
\text { that was mentioned earlier }\end{array}$ \\
\hline Citations & $\begin{array}{l}\text { Giving credit to writers of other } \\
\text { texts }\end{array}$ & According to $\mathrm{X} /(\mathrm{Y}, 1990) \mathrm{Z}$ states \\
\hline Elaborators & $\begin{array}{l}\text { Providing readers with extra } \\
\text { information of the proposition }\end{array}$ & $\begin{array}{l}\text { Namely/ e.g./ such as/ in other } \\
\text { words, this includes.../ use of } \\
\text { punctuation marks }\end{array}$ \\
\hline Category & Function & Example \\
\hline $\begin{array}{l}\text { Interpersonal } \\
\text { Discourse Markers }\end{array}$ & \multicolumn{2}{|l|}{ Help writer connects with his readers } \\
\hline Hedges & $\begin{array}{l}\text { Withhold writer's full } \\
\text { commitment to proposition }\end{array}$ & Might/perhaps/possible/about \\
\hline Emphatics & $\begin{array}{l}\text { Emphasize force or writer's } \\
\text { certainty in proposition }\end{array}$ & In fact/definitely/it is clear that \\
\hline Attitude markers & $\begin{array}{l}\text { Express writer's attitude or stance } \\
\text { to the proposition }\end{array}$ & $\begin{array}{l}\text { Unfortunately/I agree/ surprisingly, } \\
\text {...has been.../ ...were.... }\end{array}$ \\
\hline Engagement markers & $\begin{array}{l}\text { Explicitly refer to or build } \\
\text { relationship with reader }\end{array}$ & $\begin{array}{l}\text { Consider/ note that/ you can see } \\
\text { that, use of questions }\end{array}$ \\
\hline Conditionals & $\begin{array}{l}\text { Explicitly brings the reader into } \\
\text { the argument }\end{array}$ & If you..../if I were you \\
\hline Self-mentions & Explicit reference to author(s) & i/we/my/our \\
\hline
\end{tabular}

Based on the 'simplified metadiscourse framework for ESL lay writers' introduced by Tan et al.'s [6], the metadiscourse markers are classified into two main categories (organisational and interpersonal discourse markers) and sub-categories such as connectives, sequencers, topicalizers, pointers, citations, elaborators, hedges, emphatics, attitude markers, engagements markers, conditionals and self-mentions.

\section{Methodology}

This preliminary study is to discover the use of metadiscourse markers in persuasive essays written by a group of undergraduate students from a chosen public university in Malaysia, Universiti Malaysia Kelantan, Malaysia.

The sample population was drawn from undergraduate students at the University. Their essays were collected to build the main corpus of Malaysian undergraduate persuasive essays, known as MUPE corpus. The corpus built consists of 195 undergraduate essays from identified population yielding a total of 106, 568 words. These persuasive essays were taken from final examination answer scripts of an English course taken by the participants in their second year of study.

The MUPE corpus was separated into two different corpora, (1) a sub-corpus of toward good essays (which is categorised as GOOD Corpus) and (2) a sub-corpus of toward weak essays (which is categorised as WEAK Corpus). The selection of GOOD and WEAK sub-

ISSN 2774-3918 (online), https://ksshr.kresnanusantara.co.id. Published by Kresna Nusantara 


\section{Kresna Social Science and Humanities Research}

Proceedings of the International Conference On Ummah:

Digital Innovation, Humanities And Economy (ICU: DIHEc) 2020

https://doi.10.30874/ksshr.38

corpora were based on the marks graded by the lecturer or teachers. 


\section{Kresna Social Science and Humanities Research}

Proceedings of the International Conference On Ummah:

Digital Innovation, Humanities And Economy (ICU: DIHEc) 2020

https://doi.10.30874/ksshr.38

The metadiscourse markers in both sub-corpora of undergraduate persuasive essays were explored with the assistance of a concordance software, WordSmith Tools. The following Figure 1 shows the formula of metadiscourse occurrence which was used in this present study to count an occurrence per 1,000 words.

\begin{tabular}{|c|c|}
\hline $\begin{array}{l}\text { Corpus } \\
\text { (Total Words: X) }\end{array}$ & \\
\hline Total ttems & Occurrence per 1,000 words \\
\hline $\mathrm{Y}$ & $\frac{y}{x} \times 1,000=z$ \\
\hline
\end{tabular}

Figure 1: The formula to count an occurrence per 1, 000 words

\section{Findings}

Both GOOD and WEAK sub-corpora recorded a higher frequency of use in interpersonal discourse markers category as compared to organisational discourse markers category. In comparing GOOD and WEAK sub-corpora, interpersonal discourse markers category in TOWEAK corpus has a higher frequency of use based on occurrences per 1, 000 words as compared to GOOD sub-corpus. Meanwhile, organisational discourse markers category in both GOOD and WEAK sub-corpora is similar based on occurrences per 1,000 words. Although the difference is not significant which is lower than 0.45 , the number is slightly higher in WEAK corpus. It can be concluded that WEAK sub-corpus generally recorded more metadicourse items with a higher occurrence per 1, 000 words as compared to GOOD sub-corpus. It can be concluded that WEAK sub-corpus generally recorded more metadicourse items with a higher occurrence per 1, 000 words as compared to GOOD sub-corpus.

\section{Conclusion}

This preliminary study is very important as an experimental revision to analyse the metadiscourse used in a corpus of Malaysian undergraduate persuasive essays. Although the findings of this study are limited, this study is hoped to assist researchers to make comparisons and suggest more improvements to look at in the future.

Acknowledgments. The authors wish to thank the Center for Language Studies and Generic Development, Universiti Malaysia Kelantan (UMK), Malaysia for funding the process of publishing this humble work. We would like to thank the staff members who have been involved in improving this paper, directly or indirectly. The extended appreciation is finally presented to the RMIC, Universiti Malaysia Kelantan for sponsoring the study under a grant called Skim Geran Jangkamasa Pendek.

\section{References}

[1] Amiryousefi M, Rasekh, M. Metadiscourse: Definitions, Issues and Its Implications for English Teachers. ELT. 2010; 3(4)

[2] Heng $\mathrm{CH}$, Tan $\mathrm{H}$. Extracting and comparing the intricacies of metadiscourse of two written persuasive corpora. IJEDICT. 2010; 6(3): 124-146.

[3] Hyland K. Metadiscourse: Exploring interaction in writing: Continuum guides to discourse. London: Continuum; 2005.

[4] Intraprawat P, Steffensen MS. The use of metadiscourse in good and poor ESL essays. JSLW. 1995; 4(3): 253-272.

[5] Rustipa K. Metadiscourse in Indonesian EFL Learners' Persuasive Texts: A Case Study at English Department, UNISBANK. IJEL. 2014; 4(1): 44-52.

[6] Tan H, Chan SH, Abdullah AN. A proposed metadiscourse framework for lay ESL writers. WASJ. 2012; 20(1): 1-6 